\title{
Growth Forms of Gardnerella spp. and Lactobacillus spp. on Vaginal Cells
}

\begin{abstract}
Hyunsul Jung ${ }^{1}$, Marthie M. Ehlers ${ }^{1,2}$, Remco P. H. Peters ${ }^{1,3}$, Hennie Lombaard ${ }^{4}$, Mathys J. Redelinghuys ${ }^{5}$, Johanna E. Bezuidenhoudt ${ }^{6}$ and Marleen M. Kock ${ }^{1,2 *}$
\end{abstract}

${ }^{1}$ Department of Medical Microbiology, University of Pretoria, Pretoria, South Africa, ${ }^{2}$ Department of Medical Microbiology, Tshwane Academic Division, National Health Laboratory Service (NHLS), Pretoria, South Africa, ${ }^{3}$ Department of Medical Microbiology, Maastricht University, Maastricht, Netherlands, ${ }^{4}$ Wits Obstetrics and Gynaecology Clinical Research Division, Department of Obstetrics and Gynaecology, Rahima Moosa Mother and Child Hospital, University of Witwatersrand/Gauteng Department of Health, Johannesburg, South Africa, ${ }^{5}$ Wits Reproductive Health and HIV Institute, School of Clinical Medicine, University of the Witwatersrand, Johannesburg, Gauteng, South Africa, ${ }^{6}$ School of Health Systems and Public Health, University of Pretoria, Pretoria, South Africa

Bacterial vaginosis (BV) is a common vaginal condition in women of reproductive age. During BV development, BV-associated bacteria may form a polymicrobial biofilm, which predispose women to recurrent BV. The aim of the study was to investigate the growth forms of Gardnerella spp. and Lactobacillus spp. and to determine the association between the bacterial growth forms and clinical characteristics [urinary tract infection (UTI) symptoms, human immunodeficiency virus (HIV) infection and abnormal vaginal discharge] in women attending a tertiary hospital in Pretoria, South Africa. A first-void urine specimen was collected from 196 women and BV was diagnosed using the Nugent scoring and the Ison-Hay criteria (vaginal smear microscopy). Fluorescence in situ hybridisation (FISH) was performed to classify the growth forms ["dispersed" or "biofilm"]. Bacterial cells were categorized as "dispersed" if cells were scattered separately and as "biofilm" if bacterial aggregates on the vaginal epithelial cells were observed. BV was detected in 52 women (52/196; 27\%) and in these women, Gardnerella spp. were predominantly present in biofilms (46/52; 88\% for Nugent scoring; and 45/50; 90\% for Ison-Hay criteria), whereas Lactobacillus spp. were predominantly present in a dispersed form (38/52; 73\% for Nugent scoring; and 37/50; 74\% for Ison-Hay criteria). The odds of having BV increased when Gardnerella biofilms were present $(p<0.001)$, whereas the opposite was observed for Lactobacillus biofilms ( $p=0.001)$. Neither Gardnerella spp. or Lactobacillus spp. (both dispersed or biofilms) had an association with the presence of UTI symptoms, HIV coinfection or abnormal vaginal discharge. In conclusion, this study demonstrated and confirmed that Gardnerella biofilms are associated with BV and that Lactobacillus spp. may form biofilms to protect against BV.

Keywords: bacterial vaginosis, biofilm, Gardnerella spp., Lactobacillus spp., fluorescence in situ hybridization

\section{INTRODUCTION}

Bacterial vaginosis (BV) is the most common vaginal disease in women of reproductive age (Kenyon et al., 2013). BV may have a devastating impact on women's reproductive health due to its association with preterm birth (Leitich et al., 2003; Shimaoka et al., 2019), miscarriages (Hay et al., 1994) and tubal infertility (Wilson et al., 2002; van Oostrum et al., 2013). Furthermore, BV has been 
suggested to increase the risk of acquisition of sexually transmitted infections (STIs) (Allsworth and Peipert, 2011) and human immunodeficiency virus type 1 (HIV-1) (Atashili et al., 2008; van de Wijgert et al., 2008).

$\mathrm{BV}$ is a polymicrobial dysbiotic condition, which is characterized by a decrease in the normally resident lacticacid producing vaginal bacteria (usually Lactobacillus spp.) and an overgrowth of vaginal anaerobic bacteria (Hillier et al., 1993; Fredricks et al., 2005; Ravel et al., 2013). Although the exact pathogenesis of $\mathrm{BV}$ remains unknown, two main hypotheses are currently in debate to explain the BV etiology-that BV is triggered by the initial establishment of the "key bacteria" such as virulent strains of Gardnerella spp., Prevotella bivia, Atopobium vaginae and Megasphaera type 1; or it is caused by the sexual introduction of the polymicrobial community that predominantly consists of the above-mentioned "key bacteria" (Srinivasan and Fredricks, 2008; Muzny and Schwebke, 2013; Muzny et al., 2018, 2019). Gardnerella spp. have long been suggested as an etiological agent of BV since its discovery (described as Haemophilus vaginalis) by Gardner and Dukes (1955), but its role in BV etiology has remained controversial over the years because of its presence in the microbiota of "healthy" women (Zhou et al., 2004; Ravel et al., 2011; Shipitsyna et al., 2013). This controversy could partially be explained by the evidence that four different genotypes/clades (or 13 genomic species) may exist within the genus Gardnerella (Santiago et al., 2011; Ahmed et al., 2012; Vaneechoutte et al., 2019), and that there are differences in virulence potential between avirulent and virulent strains of Gardnerella spp. (Harwich et al., 2010; Janulaitiene et al., 2018).

During the initial establishment of BV, the BV-associated bacteria such as virulent strains of Gardnerella spp. may adopt the biofilm mode of growth (Swidsinski et al., 2005, 2014). The formation of a polymicrobial biofilm not only allows $\mathrm{BV}$-associated bacteria to survive and to persist against the antibiotic therapy, but also provides a shelter to tolerate hydrogen peroxide $\left(\mathrm{H}_{2} \mathrm{O}_{2}\right)$ and lactic acid produced by Lactobacillus spp. (Patterson et al., 2007; Swidsinski et al., 2008; Alves et al., 2014). Among many BV-associated bacteria that can form biofilms, virulent strains of Gardnerella spp. and A. vaginae are the predominant bacterial species actively involved in the formation of a polymicrobial BV biofilm (Swidsinski et al., 2005, 2014; Hardy et al., 2016). Gardnerella spp. are hypothesized as the "early colonizer species" that establishes a baseline for the formation of a BV biofilm, because of its strong initial adhesion ability and high biofilm formation capacity (Patterson et al., 2010; Machado et al., 2013a,b; Castro et al., 2015). Anaerobes such as $P$. bivia, A. vaginae and Megasphaera type 1 may then co-exist as a "second colonizer species" in a biofilm formed by Gardnerella spp. (Swidsinski et al., 2005; Hardy et al., 2016; Muzny et al., 2018, 2019; Castro et al., 2019).

As biofilms allow Gardnerella spp. and A. vaginae to persist after metronidazole treatment in recurrent BV (Bradshaw et al., 2006; Swidsinski et al., 2008), it could be important to study the growth form of BV-associated bacteria (especially BV biofilms), which is useful in the development of the treatment strategies. One approach to visualize the bacterial growth form and the bacterial composition in biofilms is by using fluorescence in situ hybridization (FISH) (Hardy et al., 2016). Many previous studies have successfully used FISH to demonstrate the importance of a polymicrobial biofilm in BV; however, none of these studies have directly compared each growth form of BV-associated bacteria with Ison-Hay criteria and clinical characteristics such as HIV status and urinary tract infection (UTI) symptoms (Swidsinski et al., 2005, 2014; Hardy et al., 2016). Therefore, the present study aimed to investigate the growth forms of BV-associated bacteria (Gardnerella spp. and A. vaginae) and Lactobacillus spp. on the vaginal epithelial cells in first-void urine specimens of women attending a tertiary hospital in Pretoria, South Africa, as well as to determine the association between bacterial growth forms and clinical characteristics (HIV status, presence of UTI symptoms and presence of abnormal vaginal discharge) in BVpositive women.

\section{MATERIALS AND METHODS}

\section{Study Setting and Participants}

Non-pregnant women attending a gynecology clinic and pregnant women attending a maternal and fetal unit (MAFU) at a tertiary hospital in Pretoria, South Africa were recruited from May 2014 to October 2014. The gynecology clinic provides care for outpatients who have gynecological conditions that cannot be treated at local clinics or have abnormal Pap smear test results, while the MAFU provides specialized care for pregnant women with high risk pregnancies. All adult women (18-75 years-old - see Table 1) were eligible to participate in the study if they gave written informed consent. Women were not enrolled in the study if any antibiotics were consumed at least two weeks prior to sample collection and if they menstruated at the time of sample collection or had abnormal vaginal bleeding. All procedures performed in this study involving human participants were in accordance with the ethical standards of the institutional research ethics committee (Faculty of Health Sciences Research Ethics Committee) and with the 1964 Helsinki declaration and its later amendments or comparable ethical standards. The study was approved by the Faculty of Health Sciences Research Ethics Committee, University of Pretoria (Ethics reference no.: 117/2014). Basic demographic and clinical data were obtained using a questionnaire. The UTI symptoms were defined as any of the following: frequent urination, hematuria, burning sensation, dysuria and nocturia.

\section{Classification of Vaginal Smears According to Nugent Score and Ison-Hay Criteria}

After the informed consent was obtained, a vaginal swab was collected by a physician and a smear was prepared on a frosted microscope slide (Merck KGaA, Darmstadt, Germany) immediately after the swab collection. Upon arrival at the laboratory, the vaginal smears were heat-fixed and Gram stained. Following Gram staining, vaginal smears were read and scored using the Nugent scoring system (Nugent et al., 1991) and Ison-Hay criteria (Ison and Hay, 2002). For the Nugent scoring system, a score of $0-10$ is given based on the presence or absence and counted number of three bacterial morphotypes: (i) 
TABLE 1 | Demographic, clinical and microbiological characteristics of the women included in the study.

\begin{tabular}{|c|c|c|c|}
\hline Clinical characteristics & $\begin{array}{c}\text { Non-pregnant } \\
\text { women }(n=129)\end{array}$ & $\begin{array}{l}\text { Pregnant } \\
\text { women } \\
(n=67)\end{array}$ & $p$-value ${ }^{a}$ \\
\hline \multicolumn{4}{|l|}{ Age } \\
\hline Median (range, years) & $39(18-75)$ & $29(18-42)$ & $<0.001$ \\
\hline \multicolumn{4}{|l|}{ Ethnic groups } \\
\hline African (black) & $114(88 \%)$ & $56(84 \%)$ & $0.73^{b}$ \\
\hline Caucasian (white) & $12(9.3 \%)$ & $7(10 \%)$ & \\
\hline Indian & $3(2.3 \%)$ & $2(3 \%)$ & \\
\hline Inter-racial/multi-racial & $0(0 \%)$ & $2(3 \%)$ & \\
\hline \multicolumn{4}{|l|}{ Clinical symptoms } \\
\hline \multicolumn{4}{|l|}{ Abnormal vaginal discharge } \\
\hline Present & $22(17 \%)$ & $12(18 \%)$ & 0.88 \\
\hline Absent & 107 (83\%) & 55 (82\%) & \\
\hline \multicolumn{4}{|l|}{ UTI symptoms ${ }^{\mathrm{C}}$} \\
\hline Present & $28(22 \%)$ & $18(27 \%)$ & 0.42 \\
\hline Absent & 101 (78\%) & 49 (73\%) & \\
\hline \multicolumn{4}{|l|}{ HIV $^{d}$ status } \\
\hline Positive & $67(52 \%)$ & $10(15 \%)$ & $<0.001^{b}$ \\
\hline Negative & 57 (44\%) & 57 (85\%) & \\
\hline Unknown & $5(3.9 \%)$ & $0(0 \%)$ & \\
\hline \multicolumn{4}{|c|}{ Vaginal microbiota (Nugent scoring) } \\
\hline $\begin{array}{l}\text { Nugent score } 0-3 \text { (normal } \\
\text { vaginal microbiota) }\end{array}$ & $69(53.5 \%)$ & $50(72 \%)$ & 0.016 \\
\hline $\begin{array}{l}\text { Nugent score } 4-6 \\
\text { (intermediate vaginal } \\
\text { microbiota) }\end{array}$ & $20(15.5 \%)$ & $5(7 \%)$ & \\
\hline Nugent score 7-10 (BVe) & $40(31 \%)$ & $12(20 \%)$ & \\
\hline \multicolumn{4}{|c|}{ Vaginal microbiota (Ison-Hay criteria) } \\
\hline $\begin{array}{l}\text { Class I (normal vaginal } \\
\text { microbiota) }\end{array}$ & $62(48.1 \%)$ & $48(72 \%)$ & $0.013^{g}$ \\
\hline $\begin{array}{l}\text { Class II (intermediate vaginal } \\
\text { microbiota) }\end{array}$ & $24(18.6 \%)$ & $8(12 \%)$ & \\
\hline Class III (BV) & $39(30.2 \%)$ & $11(16 \%)$ & \\
\hline $\begin{array}{l}\text { Class IV (Gram-positive cocci } \\
\text { only) }\end{array}$ & $1(0.8 \%)$ & $0(0 \%)$ & \\
\hline $\begin{array}{l}\text { Class } 0 \text { (Epithelial cells with no } \\
\text { bacteria) }^{\dagger}\end{array}$ & $3(2.3 \%)$ & $0(0 \%)$ & \\
\hline
\end{tabular}

${ }^{a} \chi^{2}$ test for independence. Significant $p$-values $(<0.05)$ are indicated in bold.

${ }^{b}$ For African vs. Caucasian and for HIV-positive vs. HIV-negative.

${ }^{c}$ Urinary tract infection symptoms: frequent urination, hematuria, burning sensation,

dysuria, nocturia.

${ }^{d}$ HIV: Human immunodeficiency virus.

${ }^{e} B V$ : bacterial vaginosis.

${ }^{f}$ Equivalent to a Nugent score of 4 (intermediate vaginal microbiota).

${ }^{g}$ Excluding classes $\mathrm{N}$ and $\mathrm{O}$.

Gram-positive rods (vaginal lactobacilli); (ii) Gram-negative to Gram-variable short rods (Gardnerella spp. /Bacteroides spp.); and (iii) Gram-negative curved rods (Mobiluncus spp.) (Nugent et al., 1991). A score of 0 to 3 is considered to be "normal" microbiota, a score of 4 to 6 is considered to be "intermediate" microbiota and a score of 7 to 10 is considered to be "bacterial vaginosis" (Nugent et al., 1991). The Ison-Hay criteria categorize the vaginal smears into five classes of microbiota, namely: (i) class I (normal microbiota, lactobacilli only); (ii) class II (intermediate microbiota, reduced lactobacilli with mixed bacterial morphotypes); class III (bacterial vaginosis, few or absent lactobacilli with mixed bacterial morphotypes); class IV (epithelial cells with only Gram-positive cocci) and class 0 (epithelial cells with no bacteria) (Ison and Hay, 2002). All slides were re-read at a later stage and were examined by a second examiner for quality control purposes.

\section{Processing of Urine Specimens}

A first-void urine specimen for the FISH examination of the bacterial growth forms on the vaginal epithelial cells was collected from each enrolled woman after informed consent was obtained. A first-void urine specimen was selected for practical purposes because it is easier to collect, and the fixed sample can be stored for long periods of time until the FISH assays are performed. Upon arrival at the laboratory, all collected first-void urine specimens were processed prior to performing the FISH assay as described in Swidsinski et al. (2010) with some modifications. In brief, the cells in $1.5 \mathrm{~mL}$ of first-void urine were collected by centrifugation (Spectrafuge ${ }^{\mathrm{TM}} 24 \mathrm{D}$ Digital Micro-centrifuge, Labnet International Inc., Edison, NJ, USA) at $6,000 \times g$ for $6 \mathrm{~min}$ and were fixed in $1 \mathrm{~mL}$ of $4 \%(\mathrm{v} / \mathrm{v})$ formaldehyde (Merck KGaA, Darmstadt, Germany) in 1x phosphate-buffered saline (PBS) buffer (pH 7.2; Gibco ${ }^{\circledR}$, Thermo Fisher Scientific Inc., Waltham, MA, USA) for $1 \mathrm{~h}$. The pellet was washed with 1x PBS buffer (pH 7.2; Gibco ${ }^{\circledR}$, Thermo Fisher Scientific Inc., Waltham, MA, USA) three times and was resuspended in a 1:1 mixture of 1x PBS and ice-cold 100\% ethanol (Merck KGaA, Darmstadt, Germany). The fixed cell suspension was stored at $4^{\circ} \mathrm{C}$ until further analysis.

\section{The Probe Specificity Test and the FISH Assay}

The probe specificity tests were performed on the following probes: (i) GardV (Swidsinski et al., 2005); (ii) Ato291 (Harmsen et al., 2000); (iii) Lab158 (Harmsen et al., 1999); (iv) Enc38a (Frahm et al., 1998); and (v) Eub338 probes (Amann et al., 1990). GardV, Ato291 and Lab158 probes are oligonucleotide probes that were previously used to visualize Gardnerella spp., A. vaginae and Lactobacillus spp. in a study by Swidsinski et al. (2005) (see Table 2 for information regarding the probes used in the FISH assay). As the Lab158 probe targets both Lactobacillus spp. and Enterococcus spp. (Harmsen et al., 1999), the Lab158-positive samples with a negative signal to the Enc38a probe specific to Enterococcus spp. were considered positive for Lactobacillus spp. The Eub338 probe is a broadrange oligonucleotide probe that targets eubacteria (Amann et al., 1990). The specificity of each probe was tested using reference strains ( $G$. vaginalis $\mathrm{ATCC}^{\circledR} 14018^{\mathrm{TM}}$ and $14019^{\mathrm{TM}}$; A. vaginae ATCC ${ }^{\circledR}$ BAA-55 ${ }^{\mathrm{TM}}$; L. crispatus $\mathrm{ATCC}^{\circledR} 33820^{\mathrm{TM}}$ ). For culturing of reference strains, a single pure colony of $A$. vaginae $\mathrm{ATCC}^{\circledR}$ BAA- $55^{\mathrm{TM}}$ was inoculated in tryptone soya broth (TSB) (Oxoid, Thermo Fisher Scientific Inc., Waltham, MA, USA), G. vaginalis ATCC ${ }^{\circledR} 14018^{\mathrm{TM}}$ and $14019^{\mathrm{TM}}$ in brain heart infusion (BHI) broth (Lab M Limited, Heywood, UK) and L. crispatus ATCC ${ }^{\circledR} 33820^{\mathrm{TM}}$ in de Man, Rogosa and Sharpe 
TABLE 2 | Oligonucleotide sequences of probes that were used in the FISH assay.

\begin{tabular}{|c|c|c|c|c|}
\hline Probe name & Target & Nucleotide sequence $\left(5^{\prime}\right.$ to $\left.3^{\prime}\right)$ & Fluorochrome label & References \\
\hline \multicolumn{5}{|l|}{ Assay 1} \\
\hline Ato291 & Atopobium cluster & GGTCGGTCTCTCAACCC & Суза & Harmsen et al., 2000 \\
\hline Eub338 & Eubacteria & GCTGCCTCCCGTAGGAGT & $6-$ FAM $^{b}$ & Amann et al., 1990 \\
\hline GardV & $\begin{array}{l}\text { Probe derived from Bif662 with } 0 \\
\text { mismatches to G. vaginalis }\end{array}$ & CCACCGTTACACCGCGAA & Cy5 $5^{\mathrm{b}}$ & Swidsinski et al., 2005 \\
\hline \multicolumn{5}{|l|}{ Assay 2} \\
\hline Enc38a & Enterococcus spp. & СТСТАССТССАТСАТТСТ & Cy5 & Frahm et al., 1998 \\
\hline Eub338 & Eubacteria & GCTGCCTCCCGTAGGAGT & 6-FAM & Amann et al., 1990 \\
\hline Lab158 & $\begin{array}{l}\text { Lactobacillus spp. and Enterococcus } \\
\text { spp. }\end{array}$ & GGTATTAGCA(C/T)CTGTITCCA & Су3 & Harmsen et al., 1999 \\
\hline
\end{tabular}

${ }^{a}$ Cy3 refers to carbocyanine attached at the $3^{\prime}$ end of oligonucleotides.

${ }^{b}$ Cy5 and 6-FAM are attached at the 5' end of oligonucleotides.

(MRS) broth (Oxoid, Thermo Fisher Scientific Inc., Waltham, MA, USA). The TSB inoculated with $A$. vaginae ATCC ${ }^{\circledR}$ BAA$55^{\mathrm{TM}}$ and the MRS broth inoculated with $L$. crispatus ATCC ${ }^{\circledR}$ $33820^{\mathrm{TM}}$ were incubated at $37^{\circ} \mathrm{C}$ for $48 \mathrm{~h}$ in an anaerobic jar (bioMérieux, Marcy l'Etoile, France) using an anaerobic gas generator (GENbox anaer, bioMérieux, Marcy l'Etoile, France). The BHI broth inoculated with either $G$. vaginalis ATCC ${ }^{\circledR}$ $14018^{\mathrm{TM}}$ or $G$. vaginalis $\mathrm{ATCC}^{\circledR} 14019^{\mathrm{TM}}$ was incubated in a carbon dioxide $\left(\mathrm{CO}_{2}\right)$ incubator (HR212UV, Shanghai Lishen Scientific Equipment Co. Ltd., Shanghai, China) with 5\% $\mathrm{CO}_{2}$ at $37^{\circ} \mathrm{C}$ for $48 \mathrm{~h}$. The FISH protocol by Amann (1995) with some modifications was followed for hybridization reactions of the oligonucleotide probes. A volume of $2 \mathrm{~mL}$ cultured broth was centrifuged (Spectrafuge $^{\mathrm{TM}}$ 24D Digital Micro-centrifuge, Labnet International Inc., Edison, NJ, USA) at $6,000 \times g$ for 6 min to obtain a pellet. The supernatant was discarded, and the cell pellet was resuspended in $100 \mu \mathrm{L}$ of PBS buffer ( $\mathrm{pH} 7.2$; Gibco ${ }^{\circledR}$, Thermo Fisher Scientific Inc., Waltham, MA, USA). A volume of $100 \mu \mathrm{L} 4 \%(\mathrm{v} / \mathrm{v})$ formaldehyde (Merck KGaA, Darmstadt, Germany) in a PBS buffer ( $\mathrm{pH} 7.2$; Gibco $^{\circledR}$, Thermo Fisher Scientific Inc., Waltham, MA, USA) was added to fixate the cells and the mixture was incubated at room temperature $\left(25 \pm 5^{\circ} \mathrm{C}\right)$ for $1 \mathrm{~h}$. After incubation, the mixture was washed twice with 1x PBS buffer ( $\mathrm{pH} 7.2$; Gibco ${ }^{\circledR}$, Thermo Fisher Scientific Inc., Waltham, MA, USA) to remove the formaldehyde completely. The washed mixture was vortexed (Vortex Mixer VX-200, Labnet International Inc., Edison, NJ, USA) and diluted 1:10 in a PBS buffer (pH 7.2; Gibco ${ }^{\circledR}$, Thermo Fisher Scientific Inc., Waltham, MA, USA). An aliquot of $10 \mu \mathrm{L}$ of the dilution was added to each well of the polytetrafluoroethylene (PTFE)-coated microscope slide (Thermo Fisher Scientific Inc., Waltham, MA, USA) and the slide was air-dried for $20 \mathrm{~min}$ at $50^{\circ} \mathrm{C}$ (Techne HB-1D, Bibby Scientific Limited, Stone, UK). A volume of $20 \mu \mathrm{L}$ of $1 \%(w / v)(10$ $\mathrm{mg} \cdot \mathrm{mL}^{-1}$ ) lysozyme solution (Sigma-Aldrich Co., St. Louis, MO, USA) was added to each well of the slide prior to hybridization and the slide was incubated for $30 \mathrm{~min}$ at $56^{\circ} \mathrm{C}$ (Techne $\mathrm{HB}-1 \mathrm{D}$, Bibby Scientific Limited, Stone, UK). After incubation, $8 \mu \mathrm{L}$ of hybridization buffer [containing $5 \mathrm{M} \mathrm{NaCl}$ solution, $1 \mathrm{M}$ Tris$\mathrm{HCl}, 10 \%$ sodium dodecyl sulfate (SDS) and sterile water] and
$1 \mu \mathrm{L}$ of working solution of each probe $\left(30 \mathrm{ng} \cdot \mu \mathrm{L}^{-1}\right.$ for Cy3 and Cy5 labeled probes; $50 \mathrm{ng} \cdot \mu^{-1}$ for 6-FAM labeled probes) were added to the wells. Hybridization of oligonucleotide probes (GardV, Ato291, Lab158, Enc38a, and Eub338) was performed in a hybridization oven (Techne HB-1D, Bibby Scientific Limited, Stone, UK) at $50^{\circ} \mathrm{C}$ for $16 \mathrm{~h}$. After hybridization, the slides were rinsed briefly with distilled water and the $4^{\prime}, 6^{\prime}$-diamidino-2phenylindole (DAPI) stain (PureBlu ${ }^{\mathrm{TM}}$ DAPI Nuclear Staining Dye, Bio-Rad Laboratories Inc., Hercules, CA, USA) was added to counter-stain the DNA of bacteria, fungi and host cells present. The slides were incubated in the dark at room temperature (25 $\pm 5^{\circ} \mathrm{C}$ ) for $15 \mathrm{~min}$. Finally, a few drops of anti-fading mounting agent (ProLong ${ }^{\circledR}$ Diamond Antifade Mountant, Thermo Fisher Scientific Inc., Waltham, MA, USA) were applied and a cover slip was placed on each slide.

Two triplex FISH assays (assay 1: GardV-Cy5, Ato291-Cy3, and Eub338-FAM probes; assay 2: Lab158-Cy3, Enc38a-Cy5, and Eub338-FAM probes) were performed without formamide at $50^{\circ} \mathrm{C}$ for $16 \mathrm{~h}$ according to the standard protocol by Amann (1995) with some modifications. An aliquot of 10 $\mu \mathrm{L}$ of the fixed cell suspension was added to each well of the polytetrafluoroethylene (PTFE)-coated microscope slide (Thermo Fisher Scientific Inc., Waltham, MA, USA) and the slide was air-dried for $20 \mathrm{~min}$ at $56^{\circ} \mathrm{C}$ (Techne HB-1D, Bibby Scientific Limited, Stone, UK). The cell smears were dehydrated for $5 \mathrm{~min}$ each in an increasing ethanol series [50, 80, and 96\% ethanol (v/v)] (Merck KGaA, Darmstadt, Germany). A volume of $20 \mu \mathrm{L}$ of lysozyme solution $\left(10 \mathrm{mg} \cdot \mathrm{mL}^{-1}\right)$ (Merck KGaA, Darmstadt, Germany) was added to each well of the slide prior to hybridization and the slide was incubated for $30 \mathrm{~min}$ at $56^{\circ} \mathrm{C}$ (Techne HB-1D, Bibby Scientific Limited, Stone, $\mathrm{UK})$ to allow better penetration of the oligonucleotide probes. After incubation, hybridization reaction was performed at $50^{\circ} \mathrm{C}$ (Techne HB-1D, Bibby Scientific Limited, Stone, UK) for $16 \mathrm{~h}$ after adding the hybridization buffer and working solution of each probe to the wells as described above. The microscope slides were rinsed briefly after the incubation in the washing buffer [containing $5 \mathrm{M} \mathrm{NaCl}$ solution, $1 \mathrm{M}$ Tris- $\mathrm{HCl}, 10 \%$ sodium dodecyl sulfate (SDS), and sterile water] and were incubated at 


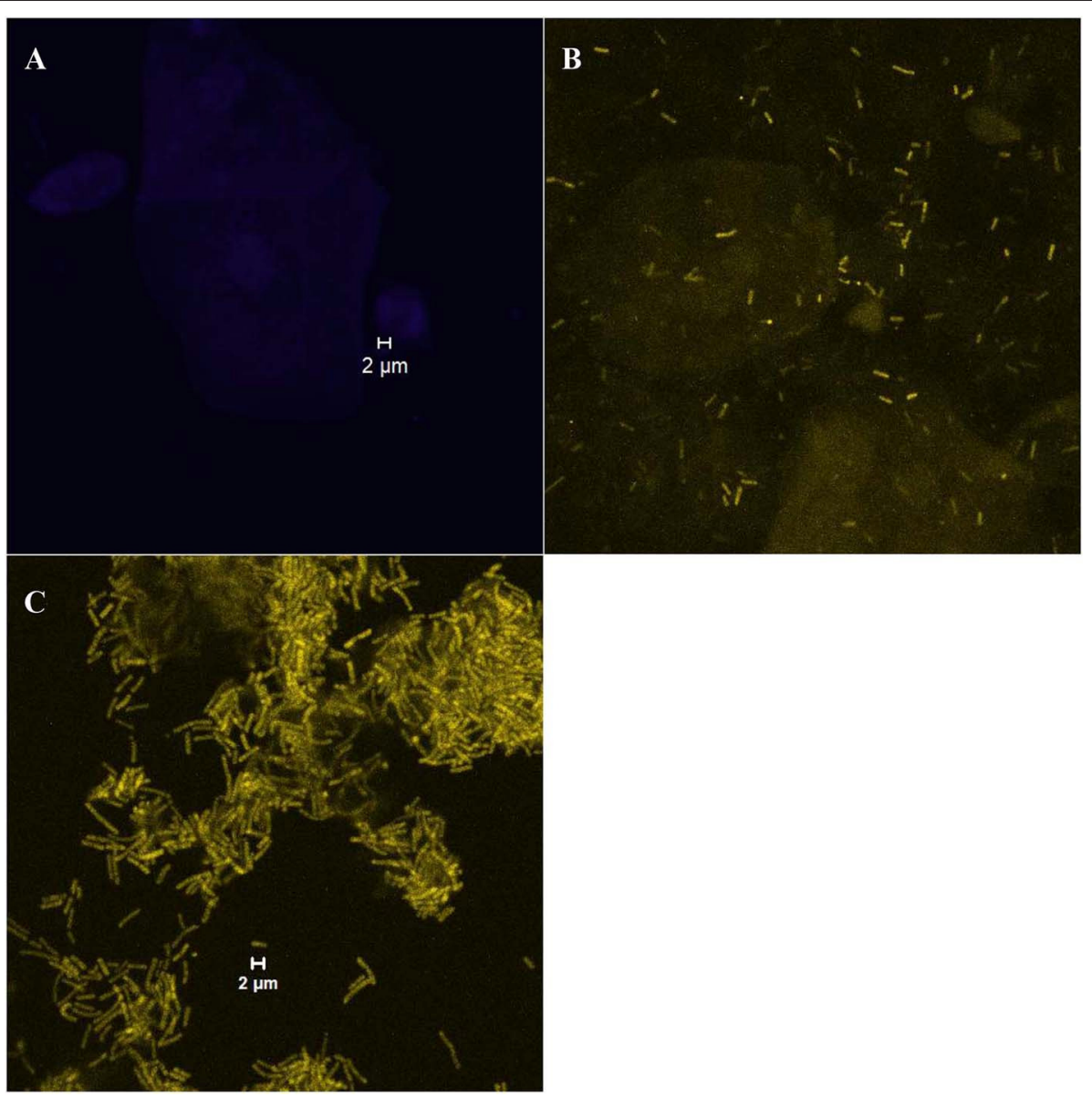

FIGURE 1 | Examples of different bacterial growth forms; (A) "absent" category with no bacteria present on vaginal cells (visualized with the laser diode 405 that detects the DAPI stain); (B) "dispersed" category [an example of scattered cells of Lactobacillus spp. (rods in yellow color) visualized with the helium-neon laser 2 that detects the Lab158-Cy3 probe]; (C) "biofilm" category ([an example of the Lactobacillus biofilm (rods in yellow color) visualized with the helium-neon laser 2]).

$50^{\circ} \mathrm{C}$ (Techne HB-1D, Bibby Scientific Limited, Stone, UK) for $10 \mathrm{~min}$. The slides were rinsed briefly with distilled water and the $4^{\prime}, 6^{\prime}$-diamidino-2-phenylindole (DAPI) stain (PureBlu ${ }^{\mathrm{TM}}$ DAPI Nuclear Staining Dye, Bio-Rad Laboratories Inc., Hercules, CA, USA) was added to counter-stain the DNA of bacteria, fungi and host cells present. The slides were incubated in the dark at room temperature $\left(25 \pm 5^{\circ} \mathrm{C}\right)$ for $15 \mathrm{~min}$. Finally, a few drops of anti-fading mounting agent (ProLong ${ }^{\circledR}$ Diamond Antifade Mountant, Thermo Fisher Scientific Inc., Waltham, MA, USA) were applied and a cover slip was placed on each slide.

\section{Fluorescence Microscopic Visualization and Bacterial Growth Phenotype}

The Zeiss LSM 510 META Laser Scanning Confocal Microscope (Carl Zeiss Microscopy GmbH, Jena, Germany; objective: PlanNeofluar 100x/1.3 oil immersion lens) and its accompanying software (Version 3.2 service pack 2, Carl Zeiss Microscopy $\mathrm{GmbH}$, Jena, Germany) were used to detect the fluorescence signal of the hybridized oligonucleotide probes. The fluorescent cells were observed using the Plan-Neofluar objective $(100 \mathrm{x}$, oil immersion lens; Carl Zeiss Microscopy GmbH, Jena, Germany) An argon laser (detecting excitation at 458, 477, 488, and $514 \mathrm{~nm}$ ) was used to detect the EUB338 probe, while a heliumneon laser 1 (detecting excitation at $543 \mathrm{~nm}$ ) and heliumneon laser 2 (detecting excitation at $633 \mathrm{~nm}$ ) were used for the Cy3-labeled (Ato291 or Lab158) and Cy5-labeled probes (GardV or Enc38a), respectively. Lastly, a laser diode 405 (detecting excitation at $405 \mathrm{~nm}$ ) was used to observe the cells stained with the DAPI stain. Ten microscopic fields were inspected per each sample to determine the presence or absence of each growth form. The fluorescence signal for species-specific probes (GardV, Ato291, Lab158, Enc38a) was considered positive if a fluorescence signal for the universal bacterial probe (Eub338) was detected simultaneously at the same position.

The growth forms of Gardnerella spp. and Lactobacillus on vaginal cells were classified into two categories, i.e., "dispersed" or "biofilm". The samples were evaluated as the "dispersed" category if bacterial cells were separately scattered (Figure 1B) and as the "biofilm" category if characteristic bacterial aggregates attached on the vaginal epithelial cells were observed (Figure 1C). The 
TABLE 3 | Probe specificity test results of the oligonucleotide probes using reference strains.

\begin{tabular}{|c|c|c|c|c|c|c|}
\hline Bacterial species & Strains & Ato291 & GardV & Lab158 & Enc38a & Eub338 \\
\hline Atopobium vaginae & ATCC $^{\circledR}$ BAA $-55^{\text {TM }}$ & $+^{a}$ & $-b$ & - & - & + \\
\hline Gardnerella vaginalis & ATCC $^{\circledR} 14018^{\text {TM }}$ & - & + & - & - & + \\
\hline Gardnerella vaginalis & ATCC $^{\circledR} 14019^{\text {TM }}$ & - & + & - & - & + \\
\hline Lactobacillus crispatus & ATCC $^{\circledR} 33820^{\text {TM }}$ & + & - & + & - & + \\
\hline
\end{tabular}

${ }^{a}(+)$ : presence of hybridization.

${ }^{b}(-)$ : absence of hybridization.

samples with no bacteria present on vaginal cells were classified into the "absent" category (Figure 1A).

\section{Statistical Analysis}

Statistical analysis was performed using the Stata 14.0 software (StataCorp LP, College Station, TX, USA). Descriptive statistics were provided as number (proportion) or median (range); proportions were compared between groups using the $\chi^{2}$ test. The agreement between Nugent scoring and the Ison-Hay criteria was measured using the Kappa $(\kappa)$ value. Forward stepwise logistic regression models based on the likelihood ratio method were fitted with BV status (BV-positive and BV-negative) as outcome, two bacterial growth forms ("dispersed" or "biofilm") as exposure (dependent variable) and the "absent" category as a reference category. Lastly, the association between two categories of bacterial growth forms and three clinical characteristics (HIV status, presence/absence of UTI symptoms and presence/absence of abnormal vaginal discharges) was determined, in which only BV-positive women were included in the analysis. Fisher's exact test was used for comparing proportions between bacterial growth forms and clinical characteristics as these categories had small sample size. The odds ratios (ORs) were reported with the $95 \%$ confidence intervals (CI). All statistical values were considered significant for $p<0.05$ (95\% CI).

\section{RESULTS}

\section{Study Participants/Population}

One hundred and twenty-nine non-pregnant women from the gynecology clinic and 67 pregnant women from the MAFU were included in the study. Women recruited at the gynecology outpatient clinic were generally older (39 years vs. 29 years; $p<0.001)$, more often HIV-infected (52\% vs. $15 \%$; $p<$ $0.001)$ and more often diagnosed with BV (31\% vs. $20 \%$; $p=$ 0.016 for Nugent Score; $30 \%$ vs. $16 \%$; $p=0.013$ for Ison-Hay criteria) (Table 1). The Nugent scoring system revealed that 52 women (27\%) were BV-positive, while 25 women (13\%) had intermediate vaginal microbiota and 119 women (61\%) had normal vaginal microbiota. Nine smears that had normal vaginal microbiota by Nugent scoring $(9 / 119 ; 7.6 \%)$ were assigned to class II by the Ison-Hay criteria; one smear that had intermediate vaginal microbiota $(1 / 21 ; 5 \%)$ were assigned to class III and three smears that were BV-positive by Nugent scoring (3/52; $6 \%)$ were assigned to class II. Among the smears that had intermediate vaginal microbiota by Nugent scoring, three smears were assigned to class $0(3 / 25 ; 12 \%)$ and one smear was assigned to class IV $(1 / 25 ; 4 \%)$. The $\kappa$ value of agreement between Nugent scoring and Ison-Hay criteria was 0.88 (95\% CI: 0.77 - 0.98).

\section{Probe Specificity Results}

The GardV and Lab158 probes were specific for each target (i.e., had a positive signal for $G$. vaginalis ATCC $^{\circledR} 14018^{\mathrm{TM}}$ and $14019^{\mathrm{TM}}$ and L. crispatus ATCC ${ }^{\circledR} 33820^{\mathrm{TM}}$, respectively and did not cross-hybridize with other reference strains) (Table 3 ). The Ato291 probe had a positive signal for A. vaginae ATCC ${ }^{\circledR}$ BAA-5 $5^{\mathrm{TM}}$; however, the Ato291 probe cross-hybridized with L. crispatus ATCC ${ }^{\circledR} 33820^{\mathrm{TM}}$. Consequently, the FISH results obtained from the Ato291 probe hybridization were excluded from the analysis.

\section{Growth Forms of Gardnerella spp. and Lactobacillus spp. on Vaginal Epithelial Cells}

Gardnerella spp. were mostly present in biofilms (76/196; 39\%), whereas Lactobacillus spp. were mostly present in a dispersed form $(115 / 196 ; 59 \%)$. Among the samples that contained Gardnerella spp. only (i.e., samples without Lactobacillus spp.; $16 / 196 ; 8.2 \%), 15$ had biofilms $(15 / 16 ; 94 \%)$ and one had a dispersed form $(1 / 16 ; 6 \%)$. Among the samples that contained Lactobacillus spp. only (i.e., samples without Gardnerella spp.; 98/196; 50\%), 60 had a dispersed form (60/98; 61\%) and 38 formed biofilms (38/98; 39\%). Dispersed Gardnerella spp. $(9 / 196 ; 4.6 \%)$ were observed with equal amounts of dispersed form $(4 / 9 ; 44 \%)$ and biofilm $(4 / 9 ; 44 \%)$ of Lactobacillus spp., respectively. Gardnerella biofilms were mostly observed when Lactobacillus spp. were dispersed $(51 / 76 ; 67 \%)$ but some samples with Gardnerella biofilms were also observed with Lactobacillus biofilms (10/76; 13\%). Thirteen samples (13/196; 6.6\%) did not contain either Gardnerella spp. or Lactobacillus spp.

Gardnerella biofilms were detected in 88\% (46/52) of samples from BV-positive women and no dispersed Gardnerella spp. was observed in samples from BV-positive women (Table 4). There was a significant difference $(p<0.001)$ between growth forms of Gardnerella spp. and between Nugent score categories. The majority of dispersed Lactobacillus spp. (63/115; 55\%) and the Lactobacillus biofilms (43/52; 83\%) were observed in samples from women with normal vaginal microbiota (Table 4). There was also a significant difference $(p<0.001)$ between growth forms of Lactobacillus spp. and between Nugent score categories. Similar observations were obtained for the Ison-Hay criteria (Table 4). 


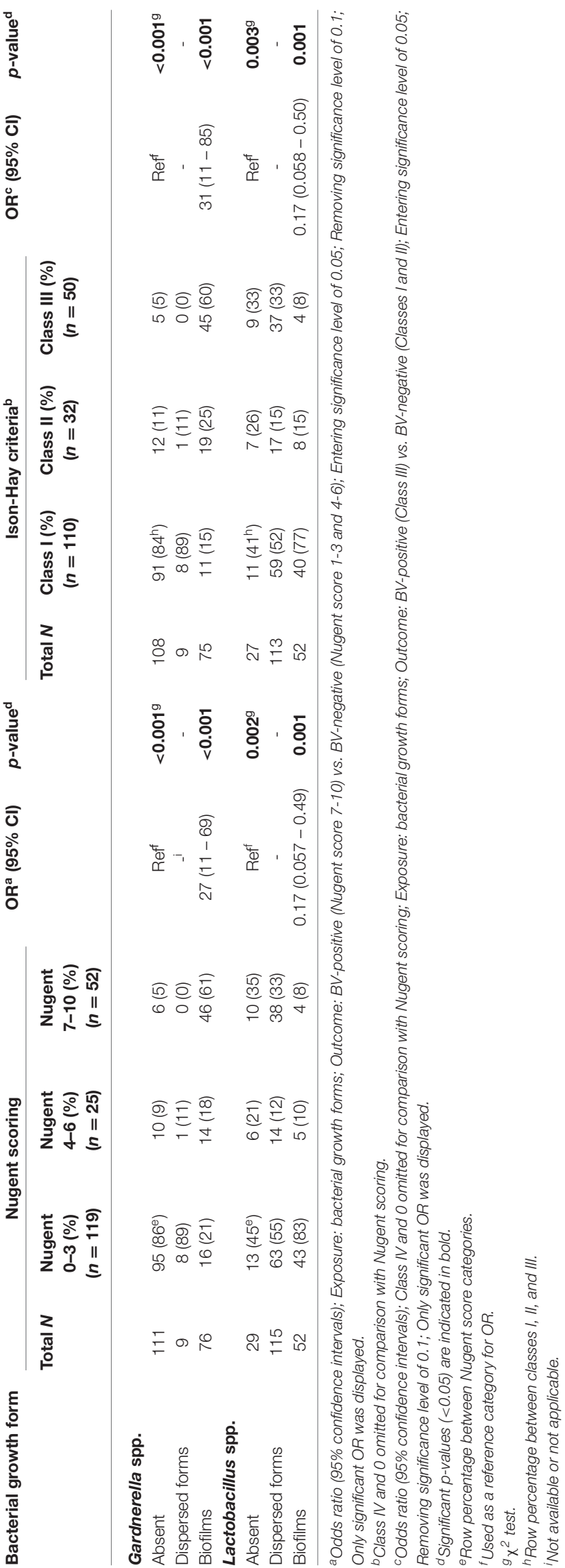

\section{Association of Biofilms With Bacterial Vaginosis and Clinical Characteristics}

The odds of having BV (Nugent score $7-10$ or class III) increased when Gardnerella biofilms were present (OR 27; CI $11-69$; $p<$ 0.001 for Nugent scoring; and OR 31; CI 11- 85; $p<0.001$ for Ison-Hay criteria) (Table 4). In contrast, the odds of having BV decreased when Lactobacillus spp. were present in biofilms (OR 0.17 ; CI $0.057-0.49 ; p=0.001$ for Nugent scoring; and OR 0.17; CI $0.058-0.50 ; p=0.001$ for Ison-Hay criteria). There was no significant relationship between the tested clinical characteristics and the bacterial growth forms (Tables 5, 6).

\section{DISCUSSION}

The present study set out to investigate the growth forms of Gardnerella spp. and Lactobacillus spp. on vaginal cells in first-void urine specimens of enrolled South African women with normal vaginal microbiota, intermediate vaginal microbiota and BV using FISH. The findings in this study demonstrate that Gardnerella spp. are predominantly present in biofilms on vaginal cells of BV-positive women, while Lactobacillus spp. are present in a dispersed growth form. The study also confirms that biofilms formed by Gardnerella spp. increase the odds of having $\mathrm{BV}$ and that Lactobacillus biofilms have the opposite effect.

The presence of Gardnerella biofilms in the majority of BVpositive women and the association of Gardnerella biofilms with BV observed in this study is a common observation confirmed by previous studies (Swidsinski et al., 2005, 2010; Hardy et al., 2015). It can be hypothesized that Gardnerella spp. may prefer to choose the biofilm form of growth during $\mathrm{BV}$ as it provides protection against antimicrobial substances like $\mathrm{H}_{2} \mathrm{O}_{2}$ and lactic acid (Patterson et al., 2007), as well as antibiotics/antiseptics (Swidsinski et al., 2008, 2015). Indeed, virulent strains of Gardnerella spp. are known strong biofilm formers with good adherence ability, which outcompete other BV-associated anaerobes (Patterson et al., 2010; Machado et al., 2013a; Alves et al., 2014; Castro et al., 2015). For this reason, Gardnerella spp. have recently been suggested as the main "early colonizer species" that displace lactobacilli and form a biofilm to create a favorable environment for other BV-associated bacteria such as Prevotella bivia, A. vaginae and Megasphaera type 1 (Machado et al., 2013a; Swidsinski et al., 2014; Hardy et al., 2015; Muzny et al., 2019).

Interestingly, the present study revealed that Lactobacillus biofilms can decrease the odds of having BV in women. The Lactobacillus biofilms were observed more frequently in women with normal vaginal microbiota than in BV-positive women $(43 / 52 ; 83 \%$ vs. $4 / 52 ; 8 \%$ for Nugent scoring and $40 / 52 ; 77 \%$ vs. $4 / 52$; $8 \%$ for Ison-Hay criteria) and had an inverse association with $\mathrm{BV}(p=0.001$ for Nugent scoring; and $p=0.001$ for Ison-Hay criteria) in this study. These observations could possibly support previous findings that some vaginal lactobacilli may form a biofilm to disrupt and prevent the colonization of pathogenic bacteria (Saunders et al., 2007; Leccese Terraf et al., 2014; Ventolini, 2015). It could also be proposed that lactobacilli may form biofilms to prevent the 
TABLE 5 | Association of growth forms of Gardnerella spp. and Lactobacillus species in relation to clinical characteristics in BV-positive women (Nugent scoring).

\begin{tabular}{|c|c|c|c|c|c|c|c|c|c|c|c|c|}
\hline \multirow[t]{2}{*}{ Bacterial growth form } & \multicolumn{4}{|c|}{ HIV status } & \multicolumn{4}{|c|}{ UTI symptoms } & \multicolumn{4}{|c|}{ Abnormal vaginal discharge } \\
\hline & $\begin{array}{c}\text { HIV-negative } \\
(\%)(n=19)\end{array}$ & $\begin{array}{l}\text { HIV-positive } \\
(\%)(n=33)\end{array}$ & $\begin{array}{c}\mathrm{OR}^{\mathrm{a}}(95 \% \\
\quad \mathrm{Cl})\end{array}$ & $p$-value & $\begin{array}{c}\text { Absent (\%) } \\
(n=39)\end{array}$ & $\begin{array}{l}\text { Present (\%) } \\
\quad(n=13)\end{array}$ & $\begin{array}{c}\mathrm{OR}^{\mathrm{b}}(95 \% \\
\quad \mathrm{Cl})\end{array}$ & $p$-value & $\begin{array}{c}\text { Absent (\%) } \\
(n=41)\end{array}$ & $\begin{array}{l}\text { Present (\%) } \\
\quad(n=11)\end{array}$ & $\mathrm{OR}^{\mathrm{c}}(95 \% \mathrm{Cl})$ & $p$-value \\
\hline \multicolumn{13}{|l|}{ Gardnerella spp. } \\
\hline Absent & $2\left(11^{d}\right)$ & $4(12)$ & $\operatorname{Ref}^{e}$ & $1.0^{f}$ & $4\left(10^{d}\right)$ & $2(15)$ & $\operatorname{Ref}^{\mathrm{e}}$ & $0.63^{f}$ & $6\left(15^{d}\right)$ & $0(0)$ & $\operatorname{Ref}^{e}$ & $0.32^{f}$ \\
\hline Dispersed & $0(0)$ & $0(0)$ & -9 & - & $0(0)$ & $0(0)$ & - & - & $0(0)$ & $0(0)$ & - & - \\
\hline Biofilm & $17(89)$ & $29(88)$ & - & - & $35(90)$ & $11(85)$ & - & - & $35(76)$ & $11(100)$ & - & - \\
\hline \multicolumn{13}{|l|}{ Lactobacillus species } \\
\hline Absent & $1\left(5^{d}\right)$ & $9(27)$ & $\operatorname{Ref}^{\mathrm{e}}$ & $0.058^{f}$ & $8\left(21^{d}\right)$ & $2(15)$ & $\operatorname{Ref}^{\mathrm{e}}$ & $0.08^{f}$ & $7\left(17^{d}\right)$ & $3(27)$ & Refe & $0.53^{f}$ \\
\hline Dispersed & $15(79)$ & $23(70)$ & - & - & $30(77)$ & $8(62)$ & - & - & $30(73)$ & $8(73)$ & - & - \\
\hline Biofilm & $3(16)$ & $1(3)$ & - & - & $1(3)$ & $3(23)$ & - & - & $4(9.8)$ & $0(0)$ & - & - \\
\hline
\end{tabular}

${ }^{a}$ Odds ratio (95\% confidence interval) adjusted by pregnancy status; Exposure: bacterial growth forms; Outcome: HIV-negative vs. HIV-positive; Entering significance level of 0.05; Removing significance level of 0.1; Only significant OR was displayed.

${ }^{b}$ Odds ratio (95\% confidence interval) adjusted by pregnancy status; Exposure: bacterial growth forms; Outcome: UTI symptoms absent vs. UTI symptoms present; Entering significance level of 0.05; Removing significance level of 0.1; Only significant OR was displayed.

c Odds ratio (95\% confidence interval) adjusted by pregnancy status; Exposure: bacterial growth forms; Outcome: abnormal vaginal discharge absent vs. abnormal vaginal discharge present; Entering significance level of 0.05; Removing significance level of 0.1; Only significant OR was displayed.

${ }^{d}$ Column percentage between bacterial growth forms.

eUsed as a reference category for $O R$.

${ }^{f}$ Fisher's exact test.

gNot available or not applicable.

TABLE 6 | Association of growth forms of Gardnerella spp. and Lactobacillus species in relation to clinical characteristics in BV-positive women (Ison-Hay criteriaa).

\begin{tabular}{|c|c|c|c|c|c|c|c|c|c|c|c|c|}
\hline \multirow[t]{2}{*}{ Bacterial growth form } & \multicolumn{4}{|c|}{ HIV status } & \multicolumn{4}{|c|}{ UTI symptoms } & \multicolumn{4}{|c|}{ Abnormal discharge } \\
\hline & $\begin{array}{l}\text { HIV-negative } \\
(\%)(n=19)\end{array}$ & $\begin{array}{l}\text { HIV-positive } \\
(\%)(n=31)\end{array}$ & $\begin{array}{c}\mathrm{OR}^{\mathrm{b}}(95 \% \\
\mathrm{Cl})\end{array}$ & $p$-value & $\begin{array}{l}\text { Absent (\%) } \\
(n=37)\end{array}$ & $\begin{array}{l}\text { Present (\%) } \\
\quad(n=13)\end{array}$ & $\begin{array}{c}\mathrm{OR}^{\mathrm{c}}(95 \% \\
\mathrm{Cl})\end{array}$ & $p$-value & $\begin{array}{l}\text { Absent (\%) } \\
(n=40)\end{array}$ & $\begin{array}{l}\text { Present (\%) } \\
\quad(n=10)\end{array}$ & $\begin{array}{l}\mathrm{OR}^{\mathrm{d}}(95 \% \\
\quad \mathrm{Cl})\end{array}$ & $p$-value \\
\hline \multicolumn{13}{|l|}{ Gardnerella spp. } \\
\hline Absent & $2\left(11^{e}\right)$ & $3(10)$ & $\operatorname{Ref}^{f}$ & $1.0^{9}$ & $3\left(8^{e}\right)$ & $2(15)$ & $\operatorname{Ref}^{f}$ & $0.60^{9}$ & $5\left(13^{\mathrm{e}}\right)$ & $0(0)$ & $\operatorname{Ref}^{f}$ & $0.57^{\mathrm{g}}$ \\
\hline Dispersed & $0(0)$ & $0(0)$ & $-h$ & - & $0(0)$ & $0(0)$ & - & - & $0(0)$ & $0(0)$ & - & - \\
\hline Biofilm & $17(89)$ & $28(90)$ & - & - & $34(92)$ & $11(85)$ & - & - & $35(88)$ & $10(100)$ & - & - \\
\hline \multicolumn{13}{|l|}{ Lactobacillus species } \\
\hline Absent & $1\left(5^{\mathrm{e}}\right)$ & $8(26)$ & $\operatorname{Ref}^{f}$ & $0.065^{9}$ & $7\left(19^{\mathrm{e}}\right)$ & $2(15)$ & $\operatorname{Ref}^{f}$ & $0.11^{9}$ & $7\left(18^{\mathrm{e}}\right)$ & $2(20)$ & $\operatorname{Ref}^{f}$ & $0.86^{9}$ \\
\hline Dispersed & $15(79)$ & $22(71)$ & - & - & $29(78)$ & $8(62)$ & - & - & $29(73)$ & $8(80)$ & - & - \\
\hline Biofilm & $3(16)$ & $1(3)$ & - & - & $1(3)$ & $3(23)$ & - & - & $4(10)$ & $0(0)$ & - & - \\
\hline
\end{tabular}

${ }^{a}$ Class $I V$ and 0 omitted for comparison with Nugent scoring.

${ }^{b}$ Odds ratio (95\% confidence interval) adjusted by pregnancy status; Exposure: bacterial growth forms; outcome: HIV-negative vs. HIV-positive; Entering significance level of 0.05; Removing significance level of 0.1; only significant OR was displayed.

${ }^{c}$ Odds ratio (95\% confidence interval) adjusted by pregnancy status; Exposure: bacterial growth forms; outcome: UTI symptoms absent vs. UTI symptoms present; Entering significance level of 0.05; Removing significance level of 0.1; only significant OR was displayed.

${ }^{d}$ Odds ratio (95\% confidence interval) adjusted by pregnancy status; Exposure: bacterial growth forms; outcome: abnormal vaginal discharge absent vs. abnormal vaginal discharge present; Entering significance level of 0.05; Removing significance level of 0.1; only significant $O R$ was displayed.

${ }^{e}$ Column percentage between bacterial growth forms.

${ }^{f}$ Used as reference category for OR.

${ }^{g}$ Fisher's exact test.

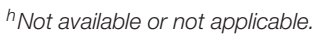


formation of a polymicrobial BV biofilm. However, lactobacilli were absent in some women with normal vaginal microbiota $(13 / 119 ; 10.9 \%$ for Nugent scoring and $11 / 110 ; 10 \%$ for IsonHay criteria), as previously reported (Zhou et al., 2004; Ravel et al., 2011). According to Ravel et al. (2011) and Zhou et al. (2004), some women may still maintain a "normal" vaginal environment without lactobacilli and that these women may contain BV-associated vaginal bacteria like $A$. vaginae, Leptotrichia spp. and Megasphaera spp., which are capable of producing lactic acid.

Lastly, the present study has attempted to determine the association between different bacterial growth forms and three clinical characteristics (HIV status, UTI symptoms and abnormal vaginal discharge) in BV-positive women. However, there was no significant association observed between the bacterial growth forms and tested clinical characteristics. This could be due to a small sample size of BV-positive women.

The present study acknowledges that there are limitations. The first limitation was that the FISH results of $A$. vaginae could not be included in the analysis due to the suboptimal specificity of the Ato291 probe. Cross-hybridization of the Ato291 probe was also observed in a study by Hardy et al. (2015), indicating that use of the peptide nucleic acid (PNA) probe instead of oligonucleotide probe could be useful in future. Another limitation is the usage of the urine specimens for detecting growth forms on the vaginal cells, which might not have adequate amounts of vaginal epithelial cells for the FISH assay as compared to vaginal swabs. Therefore, future studies should utilize the vaginal swab eluates for the FISH assays to improve results. Furthermore, as this study did not determine the clades/subgroups of Gardnerella spp., it could be beneficial to perform the clade-specific PCR assays along with the FISH assays to determine associations between the growth forms with different strains of Gardnerella spp.

In conclusion, this study demonstrated and confirmed that Gardnerella spp. form biofilms on vaginal epithelial cells of BVpositive women, whereas Lactobacillus spp. display a dispersed growth form on vaginal cells. This study also revealed that Lactobacillus spp. may form biofilms to have a protective role against BV. This study encourages further studies covering a wide

\section{REFERENCES}

Ahmed, A., Earl, J., Retchless, A., Hillier, S. L., Rabe, L. K., Cherpes, T. L., et al. (2012). Comparative genomic analyses of 17 clinical isolates of Gardnerella vaginalis provide evidence of multiple genetically isolated clades consistent with subspeciation into genovars. J. Bacteriol. 194, 3922-3937. doi: 10.1128/JB.00056-12

Allsworth, J. E., and Peipert, J. F. (2011). Severity of bacterial vaginosis and the risk of sexually transmitted infection. Am. J. Obstet. Gynecol. 205, 113.e1-6. doi: 10.1016/j.ajog.2011.02.060

Alves, P., Castro, J., Sousa, C., Cereija, T. B., and Cerca, N. (2014). Gardnerella vaginalis outcompetes 29 other bacterial species isolated from patients with bacterial vaginosis, using in an in vitro biofilm formation model. J. Infect. Dis. 210, 593-596. doi: 10.1093/infdis/jiu131

Amann, R. I. (1995). "In situ identification of micro-organisms by whole cell hybridization with rRNA-targeted nucleic acid probes," in Molecular Microbial Ecology Manual, eds. A. D. L. Akkermans, J. D. van Elsas, array of BV-associated bacteria including A. vaginae to uncover the mystery of biofilm formation mechanisms in BV.

\section{DATA AVAILABILITY STATEMENT}

The datasets generated for this study are available on request to the corresponding author.

\section{ETHICS STATEMENT}

The studies involving human participants were reviewed and approved by Faculty of Health Science Research Ethics Committee, University of Pretoria (Ethics ref. no. 117/2014). The patients/participants provided their written informed consent to participate in this study.

\section{AUTHOR CONTRIBUTIONS}

HJ was involved in the concept design, experimental work, data and statistical analysis as well as the writing and editing of the manuscript. ME, HL, MR, and MK were involved in the concept design. ME, RP, HL, MR, and MK critically reviewed the manuscript. RP and JB were involved in the statistical analysis of the acquired data.

\section{FUNDING}

This study was funded by the Medical Research Council (MRC) of South Africa and National Health Laboratory Service (NHLS) of South Africa (NHLS Research Trust development grants). The opinions and conclusions expressed in this article are those of the authors and do not necessarily reflect the opinions of the MRC and NHLS.

\section{ACKNOWLEDGMENTS}

The authors would like to thank Mr. Alan Hall from the Laboratory for Microscopy and Microanalysis, University of Pretoria, South Africa for the expertise and technical assistance with confocal laser scanning microscopy. and F. J. de Bruijn (Dordrecht: Springer Netherlands), 331-345. doi: 10.1007/978-94-011-0351-0_23

Amann, R. I., Binder, B. J., Olson, R. J., Chisholm, S. W., Devereux, R., and Stahl, D. A. (1990). Combination of $16 \mathrm{~S}$ rRNA-targeted oligonucleotide probes with flow cytometry for analyzing mixed microbial populations. Appl. Environ. Microbio. 56, 1919-1925. doi: 10.1128/AEM.56.6.1919-1925.1990

Atashili, J., Poole, C., Ndumbe, P. M., Adimora, A. A., and Smith, J. S. (2008). Bacterial vaginosis and HIV acquisition: a meta-analysis of published studies. AIDS 22, 1493-1501. doi: 10.1097/QAD.0b013e3283021a37

Bradshaw, C. S., Tabrizi, S. N., Fairley, C. K., Morton, A. N., Rudland, E., and Garland, S. M. (2006). The association of Atopobium vaginae and Gardnerella vaginalis with bacterial vaginosis and recurrence after oral metronidazole therapy. J. Infect. Dis. 194, 828-836. doi: 10.1086/506621

Castro, J., Alves, P., Sousa, C., Cereija, T., Franca, A., Jefferson, K. K., et al. (2015). Using an in-vitro biofilm model to assess the virulence potential of bacterial vaginosis or non-bacterial vaginosis Gardnerella vaginalis isolates. Sci. Rep. 5:11640. doi: 10.1038/srep11640 
Castro, J., Machado, D., and Cerca, N. (2019). Unveiling the role of Gardnerella vaginalis in polymicrobial bacterial vaginosis biofilms: the impact of other vaginal pathogens living as neighbors. ISME J. 13, 1306-1317. doi: 10.1038/s41396-018-0337-0

Frahm, E., Heiber, I., Hoffmann, S., Koob, C., Meier, H., Ludwig, W., et al. (1998). Application of $23 \mathrm{~S}$ rDNA-targeted oligonucleotide probes specific for enterococci to water hygiene control. Syst. Appl. Microbiol. 21, 450-453. doi: 10.1016/S0723-2020(98)80055-6

Fredricks, D. N., Fiedler, T. L., and Marrazzo, J. M. (2005). Molecular identification of bacteria associated with bacterial vaginosis. N. Engl. J. Med. 353, 1899-1911. doi: 10.1056/NEJMoa043802

Gardner, H. L., and Dukes, C. D. (1955). Haemophilus vaginalis vaginitis: a newly defined specific infection previously classified non-specific vaginitis. Am. J. Obstet. Gynecol. 69, 962-976. doi: 10.1016/0002-9378(55)90095-8

Hardy, L., Jespers, V., Abdellati, S., De Baetselier, I., Mwambarangwe, L., Musengamana, V., et al. (2016). A fruitful alliance: the synergy between Atopobium vaginae and Gardnerella vaginalis in bacterial vaginosis-associated biofilm. Sex. Trans. Inf. 92, 487-491. doi: 10.1136/sextrans-2015-052475

Hardy, L., Jespers, V., Dahchour, N., Mwambarangwe, L., Musengamana, V., Vaneechoutte, M., et al. (2015). Unravelling the bacterial vaginosis-associated biofilm: a multiplex Gardnerella vaginalis and Atopobium vaginae fluorescence in situ hybridization assay using peptide nucleic acid probes. PLoS ONE 10:e0136658. doi: 10.1371/journal.pone.0136658

Harmsen, H. J. M., Elfferich, P., Schut, F., and Welling, G. W. (1999). A 16 S rRNA-targeted probe for detection of lactobacilli and enterococci in faecal samples by fluorescent in situ hybridization. Microb. Ecol. Health Dis. 11, 3-12. doi: 10.3402/mehd.v11i1.7876

Harmsen, H. J. M., Wildeboer-Veloo, A. C. M., Grijpstra, J., Knol, J., Degener, J. E., and Welling, G. W. (2000). Development of 16S rRNAbased probes for the Coriobacterium group and the Atopobium cluster and their application for enumeration of Coriobacteriaceae in human feces from volunteers of different age groups. Appl. Environ. Microbiol. 66, 4523-4527. doi: 10.1128/AEM.66.10.4523-4527.2000

Harwich, M. D. Jr. Alves, J. M., Buck, G. A., Strauss, J. F. 3rd, Patterson, J. L., Oki, A. T., et al. (2010). Drawing the line between commensal and pathogenic Gardnerella vaginalis through genome analysis and virulence studies. BMC Genomics 11:375. doi: 10.1186/1471-2164-11-375

Hay, P. E., Lamont, R. F., Taylor-Robinson, D., Morgan, D. J., Ison, C., and Pearson, J. (1994). Abnormal bacterial colonisation of the genital tract and subsequent preterm delivery and late miscarriage. BMJ 308, 295-298. doi: 10.1136/bmj.308.6924.295

Hillier, S. L., Krohn, M. A., Rabe, L. K., Klebanoff, S. J., and Eschenbach, D. A. (1993). The normal vaginal flora, $\mathrm{H}_{2} \mathrm{O}_{2}$-producing lactobacilli, and bacterial vaginosis in pregnant women. Clin. Infect. Dis. 16, S273-S281. doi: 10.1093/clinids/16.Supplement 4.S273

Ison, C. A., and Hay, P. E. (2002). Validation of a simplified grading of Gram stained vaginal smears for use in genitourinary medicine clinics. Sex. Transm. Infect. 78, 413-415. doi: 10.1136/sti.78.6.413

Janulaitiene, M., Gegzna, V., Baranauskiene, L., Bulavaite, A., Simanavicius, M., and Pleckaityte, M. (2018). Phenotypic characterization of Gardnerella vaginalis subgroups suggests differences in their virulence potential. PLoS ONE 13:e0200625. doi: 10.1371/journal.pone.0200625

Kenyon, C., Colebunders, R., and Crucitti, T. (2013). The global epidemiology of bacterial vaginosis: a systematic review. Am. J. Obstet. Gynecol. 209, 505-523. doi: 10.1016/j.ajog.2013.05.006

Leccese Terraf, M. C., Mendoza, L. M., Juarez Tomas, M. S., Silva, C., and NaderMacias, M. E. (2014). Phenotypic surface properties (aggregation, adhesion, and biofilm formation) and presence of related genes in beneficial vaginal lactobacilli. J. Appl. Microbiol. 117, 1761-1772. doi: 10.1111/jam.12642

Leitich, H., Bodner-Adler, B., Brunbauer, M., Kaider, A., Egarter, C., and Husslein, P. (2003). Bacterial vaginosis as a risk factor for preterm delivery: a metaanalysis. Am. J. Obstet. Gynecol. 189, 139-147. doi: 10.1067/mob.2003.339

Machado, A., Jefferson, K. K., and Cerca, N. (2013a). Interactions between Lactobacillus crispatus and bacterial vaginosis (BV)-associated bacterial species in initial attachment and biofilm formation. Int. J. Mol. Sci. 14, 12004-12012. doi: 10.3390/ijms140612004

Machado, A., Salgueiro, D., Harwich, M., Jefferson, K. K., and Cerca, N. (2013b). Quantitative analysis of initial adhesion of bacterial vaginosis-associated anaerobes to ME-180 cells. Anaerobe 23, 1-4. doi: 10.1016/j.anaerobe.2013.07.007

Muzny, C. A., Blanchard, E., Taylor, C. M., Aaron, K. J., Talluri, R., Griswold, M. E., et al. (2018). Identification of key bacteria involved in the induction of incident bacterial vaginosis: a prospective study. J. Infect. Dis. 218, 966-978. doi: 10.1093/infdis/jiy243

Muzny, C. A., and Schwebke, J. R. (2013). Gardnerella vaginalis: still a prime suspect in the pathogenesis of bacterial vaginosis. Curr. Infect. Dis. Rep. 15, 130-135. doi: 10.1007/s11908-013-0318-4

Muzny, C. A., Taylor, C. M., Swords, W. E., Tamhane, A., Chattopadhyay, D., Cerca, N., et al. (2019). An updated conceptual model on the pathogenesis of bacterial vaginosis. J. Infect. Dis. 220, 1399-1405. doi: 10.1093/infdis/jiz342

Nugent, R. P., Krohn, M. A., and Hillier, S. L. (1991). Reliability of diagnosing bacterial vaginosis is improved by a standardized method of gram stain interpretation. J. Clin. Microbiol. 29, 297-301. doi: 10.1128/JCM.29.2.297-301.1991

Patterson, J. L., Girerd, P. H., Karjane, N. W., and Jefferson, K. K. (2007) Effect of biofilm phenotype on resistance of Gardnerella vaginalis to hydrogen peroxide and lactic acid. Am. J. Obstet. Gynecol. 197, 170.e1-7. doi: 10.1016/j.ajog.2007.02.027

Patterson, J. L., Stull-Lane, A., Girerd, P. H., and Jefferson, K. K. (2010). Analysis of adherence, biofilm formation and cytotoxicity suggests a greater virulence potential of Gardnerella vaginalis relative to other bacterial-vaginosisassociated anaerobes. Microbiology 156, 392-399. doi: 10.1099/mic.0.03 4280-0

Ravel, J., Brotman, R. M., Gajer, P., Ma, B., Nandy, M., Fadrosh, D. W., et al. (2013). Daily temporal dynamics of vaginal microbiota before, during and after episodes of bacterial vaginosis. Microbiome 1:29. doi: 10.1186/2049-2618-1-29

Ravel, J., Gajer, P., Abdo, Z., Schneider, G. M., Koenig, S. S., McCulle, S. L., et al. (2011). Vaginal microbiome of reproductive-age women. Proc. Natl. Acad. Sci. U. S. A. 108, 4680-4687. doi: 10.1073/pnas.1002611107

Santiago, G. L., Deschaght, P., El Aila, N., Kiama, T. N., Verstraelen, H., Jefferson, K. K., et al. (2011). Gardnerella vaginalis comprises three distinct genotypes of which only two produce sialidase. Am. J. Obstet. Gynecol. 204, 450.e1-7. doi: 10.1016/j.ajog.2010.12.061

Saunders, S., Bocking, A., Challis, J., and Reid, G. (2007). Effect of Lactobacillus challenge on Gardnerella vaginalis biofilms. Colloids Surf. B. Biointerfaces. 55, 138-142. doi: 10.1016/j.colsurfb.2006.11.040

Shimaoka, M., Yo, Y., Doh, K., Kotani, Y., Suzuki, A., Tsuji, I., et al. (2019). Association between preterm delivery and bacterial vaginosis with or without treatment. Sci. Rep. 9:509. doi: 10.1038/s41598-018-3 6964-2

Shipitsyna, E., Roos, A., Datcu, R., Hallen, A., Fredlund, H., Jensen, J. S., et al. (2013). Composition of the vaginal microbiota in women of reproductive agesensitive and specific molecular diagnosis of bacterial vaginosis is possible? PLoS ONE 8:e60670. doi: 10.1371/journal.pone.0060670

Srinivasan, S., and Fredricks, D. N. (2008). The human vaginal bacterial biota and bacterial vaginosis. Interdiscip. Perspect. Infect. Dis. 2008:50479. doi: $10.1155 / 2008 / 750479$

Swidsinski, A., Doerffel, Y., Loening-Baucke, V., Swidsinski, S., Verstraelen, H., Vaneechoutte, M., et al. (2010). Gardnerella biofilm involves females and males and is transmitted sexually. Gynecol. Obstet. Invest. 70, 256-263. doi: 10.1159/000314015

Swidsinski, A., Loening-Baucke, V., Mendling, W., Dorffel, Y., Schilling, J., Halwani, Z., et al. (2014). Infection through structured polymicrobial Gardnerella biofilms (StPM-GB). Histol. Histopathol. 29, 567-587.

Swidsinski, A., Loening-Baucke, V., Swidsinski, S., and Verstraelen, H. (2015). Polymicrobial Gardnerella biofilm resists repeated intravaginal antiseptic treatment in a subset of women with bacterial vaginosis: a preliminary report. Arch. Gynecol. Obstet. 291, 605-609. doi: 10.1007/s00404-0143484-1

Swidsinski, A., Mendling, W., Loening-Baucke, V., Ladhoff, A., Swidsinski, S., Hale, L. P., et al. (2005). Adherent biofilms in bacterial vaginosis. Obstet. Gynecol. 106, 1013-1023. doi: 10.1097/01.AOG.0000183594. 45524.d2

Swidsinski, A., Mendling, W., Loening-Baucke, V., Swidsinski, S., Dorffel, Y., Scholze, J., et al. (2008). An adherent Gardnerella vaginalis biofilm persists on the vaginal epithelium after standard therapy with oral 
metronidazole. Am. J. Obstet. Gynecol. 198, 97.e1-6. doi: 10.1016/j.ajog.2007. 06.039

van de Wijgert, J. H., Morrison, C. S., Cornelisse, P. G., Munjoma, M., Moncada, J., Awio, P., et al. (2008). Bacterial vaginosis and vaginal yeast, but not vaginal cleansing, increase HIV-1 acquisition in African women. J. Acquir. Immune. Defic. Syndr. 48, 203-210. doi: 10.1097/QAI.0b013e3181743936

van Oostrum, N., de Sutter, P., Meys, J., and Verstraelen, H. (2013). Risks associated with bacterial vaginosis in infertility patients: a systematic review and meta-analysis. Hum. Reprod. 28, 1809-1815. doi: 10.1093/humrep/ det096

Vaneechoutte, M., Guschin, A., van Simaey, L., Gansemans, Y., van Nieuwerburgh, F., and Cools, P. (2019). Emended description of Gardnerella vaginalis and description of Gardnerella leopoldii sp. nov., Gardnerella piatii sp. nov. and Gardnerella swidsinskii sp. nov., with delineation of 13 genomic species within the genus Gardnerella. Int. J. Syst. Evol. Microbiol. 69, 679-687. doi: 10.1099/ijsem.0.003200

Ventolini, G. (2015). Vaginal Lactobacillus: biofilm formation in vivo clinical implications. Int. J. Womens Health 7, 243-247. doi: 10.2147/IJWH. S77956
Wilson, J. D., Ralph, S. G., and Rutherford, A. J. (2002). Rates of bacterial vaginosis in women undergoing in vitro fertilisation for different types of infertility. BJOG. 109, 714-717. doi: 10.1111/j.1471-0528.2002.01297.x

Zhou, X., Bent, S. J., Schneider, M. G., Davis, C. C., Islam, M. R., and Forney, L. J. (2004). Characterization of vaginal microbial communities in adult healthy women using cultivation-independent methods. Microbiology 150, 2565-2573. doi: $10.1099 /$ mic. $0.26905-0$

Conflict of Interest: The authors declare that the research was conducted in the absence of any commercial or financial relationships that could be construed as a potential conflict of interest.

Copyright (C) 2020 Jung, Ehlers, Peters, Lombaard, Redelinghuys, Bezuidenhoudt and Kock. This is an open-access article distributed under the terms of the Creative Commons Attribution License (CC BY). The use, distribution or reproduction in other forums is permitted, provided the original author(s) and the copyright owner(s) are credited and that the original publication in this journal is cited, in accordance with accepted academic practice. No use, distribution or reproduction is permitted which does not comply with these terms. 